\title{
Host ant specificity of large blue butterflies Phengaris (Maculinea) (Lepidoptera: Lycaenidae) inhabiting humid grasslands in East-central Europe
}

\author{
Magdalena WITEK ${ }^{1 *}$, Ewa B. ŚLIWIŃSKA ${ }^{1}$, Piotr SKÓRKA ${ }^{2}$, Piotr NOWICKI ${ }^{1}$, Marta WANTUCH $^{1}$, \\ VLADIMÍR VRABEC ${ }^{3}$, JOSEF SETTELE ${ }^{4}$ and Michal WOYCIECHOWSKI ${ }^{1}$ \\ ${ }^{1}$ Institute of Environmental Sciences, Jagiellonian University, Gronostajowa 7, 30-387 Kraków, Poland \\ ${ }^{2}$ Institute of Nature Conservation, Polish Academy of Sciences, Mickiewicza 33, 31-120 Kraków, Poland \\ ${ }^{3}$ Department of Zoology and Fishery, Czech University of Life Sciences, Kamýcká 129, CZ-165 21 Prague 6 - Suchdol, \\ Czech Republic \\ ${ }^{4}$ UFZ - Helmholtz Centre for Environmental Research, Department of Community Ecology, Theodor-Lieser-Str. 4, \\ D-06120 Halle, Germany
}

Key words. Lycaenidae, host ant specificity, Phengaris, Maculinea, Myrmica, social parasitism

\begin{abstract}
Butterflies of the genus Phengaris have a highly specialised life cycle involving an obligatory relationship with $M y r m i c a$ ants. A knowledge of the host ant specificity is essential for understanding the relationship between a particular Phengaris species and its hosts and also important for the conservation of these butterflies. Data on host ant specificity were collected in Poland, the Czech Republic, Slovakia and Ukraine. Five different Myrmica species were used by P. teleius as hosts (M. scabrinodis, M. rubra, M. ruginodis, M. rugulosa and M. gallienii) and at most localities it was not possible to distinguish a primary host - i.e. several $M y r-$ mica species were parasitized to similar extents. Three populations of $P$. nausithous were found in Poland and Ukraine. In every case, $M$. rubra was its primary host, although in the Kraków region (Poland) two nests of M. scabrinodis and two of M. ruginodis were infested by this butterfly species. P. alcon in the four populations investigated in Poland and Ukraine invariably only used $M$. scabrinodis as a host despite the presence of other Myrmica species. These results obtained suggest lack of host specificity in P. teleius and high host specificity in P. nausithous, which mainly uses M. rubra as its host across Europe. Moreover, the three populations of $P$. alcon investigated seem to be highly specific and use $M$. scabrinodis as a host, which confirms the high local specialisation of these populations.
\end{abstract}

\section{INTRODUCTION}

Most of the relationships between ants and lycaenid butterflies seem to be mutualistic (Pierce, 1987; Fiedler, 1991, 2001) but in some cases, larvae of certain butterfly species can exploit ant nests as a food resource and shelter and behave as well specialized social parasites (Cottrell, 1984; Maschwitz et al., 1984; Fiedler, 2001). Probably, the most studied parasitic myrmecophilous relationship is the one between Phengaris Doherty, 1891 (a junior synonym - Maculinea van Eecke, 1915, see Fric et al., 2007) butterflies and Myrmica Latreille, 1804 ants (Thomas \& Settele, 2004). Females of Phengaris lay eggs on a specific foodplant and then after about three weeks, young larvae hatch from eggs and feed on the seeds or flowers of the plant. On reaching the fourth instar, the larvae drop to the ground and wait for foraging Myrmica ants, which take them to their nests. Phengaris caterpillars are parasites of Myrmica nests and have evolved different strategies for exploiting Myrmica host nests (Thomas \& Elmes, 1998). Caterpillars of Phengaris teleius Bergsträsser, 1779 and $P$. arion Linnaeus, 1758 prey on ant brood and are called "predatory" species (Thomas et al., 1991; Thomas \& Wardlaw, 1992), whereas those of $P$. alcon Denis \& Schiffermüller, 1775 and $P$. rebeli Hirschke, 1905 are termed "cuckoo" species, as they mimic ant larvae and are fed directly by workers (Elmes et al., 1991a, b). There is no precise information on the feeding behaviour of $P$. nausithous Bergsträsser, 1779 larvae inside Myrmica nests, but this species may have an intermediate strategy (Thomas \& Settele, 2004). The cuckoo species are more advanced in their behaviour and chemical mimicry of their host ants compared to the predatory species (Thomas \& Elmes 1998; Als et al., 2004). Moreover, the cuckoo-feeding manner is more efficient and as up to 6-7 times more imagoes are produced per ant nest compared to the predatory species of Phengaris (Thomas \& Wardlaw, 1992; Thomas et al., 1993).

Earlier work suggests that each Phengaris species has evolved to parasitize a single and different Myrmica species (Thomas et al., 1989) with each species adapted to a single "primary host" ant species and only occasionally found with other Myrmica, which are regarded as secondary hosts. Thus, M. scabrinodis Nylander, 1846 was recorded as the main host ant of $P$. teleius, while $M$. rubra Linnaeus, 1758 of $P$. nausithous, $M$. ruginodis Nylander, 1846 of P. alcon, M. schencki Emery, 1984 of

\footnotetext{
* Present and corresponding address: University of Turin, Department of Human and Animal Biology, Via Accademia Albertina 13, 10126 Torino, Italy; e-mail: mawitus@yahoo.co.uk
} 
P. rebeli and $M$. sabuleti Meinert, 1860 of $P$. arion respectively (Thomas et al., 1989).

In contrast, recent studies conducted across Europe raise doubts about high host ants specialization of Phengaris (Elmes et al., 1994, 1998; Als et al., 2002; Stankiewicz \& Sielezniew, 2002; Tartally \& Csősz, 2004; Witek et al., 2006). Based on the above reports on Phengaris host ant specificity, Pech et al. (2007) conducted a review testing two hypotheses, (a) the species specificity and (b) local specialization hypotheses. They concluded that host ant specificity is poorly supported at present and there is no clear evidence for species-specificity in $P$. teleius, $P$. alcon and $P$. rebeli. Also, local-specialization only occurs in some populations and similarly in both cuckoo and predatory species. In this paper, extensive new data on host ant specificity are presented for $P$. teleius, $P$. nausithous, $P$. alcon from four East-central European countries: Poland, the Czech Republic, Slovakia and Ukraine. Most of this information is based on comparatively large samples and sheds further light on the discussion of both the host ant species-specificity of Phengaris butterflies in Central Europe and the local specialization of particular butterfly populations. This also has important conservation implications.

\section{MATERIAL AND METHODS}

\section{Study sites}

The data on host ant specificity of $P$. teleius, $P$. nausithous and $P$. alcon were collected in four Central European countries: Poland, the Czech Republic, Slovakia and Ukraine. Information on particular field studies is presented in Fig. 1 and Appendix 1. The largest number of Myrmica nests was investigated at three sites in Poland (2520 nests). In the Czech Republic, Slovakia and Ukraine 257, 221 and 564, Myrmica nests were found. All of the localities investigated were wet grasslands where Sanguisorba officinalis Linnaeus was abundant. The data were collected from 2002 to 2004 in the case of Polish localities, and in 2005 in the Czech Republic, Slovakia and Ukraine. A total of 3562 Myrmica nests were investigated at 13 localities (Fig. 1).

\section{Methods}

Field sampling was conducted from mid June to the beginning of July, i.e. in the period shortly before butterflies start to emerge. Myrmica nests were searched for within a distance of up to $2 \mathrm{~m}$ from Phengaris food plants, which is roughly the foraging distance of Myrmica ants (Elmes et al., 1998), thus all nests examined potentially could have been parasitised. However, this was not always possible for Gentiana pneumonanthe Linnaeus as in early summer it is difficult to detect every plant of this species. In such cases Myrmica nests in parts of meadows where there were cluster of $G$. pneumonanthe were searched. All located Myrmica nests were opened to check for the presence of Phengaris larvae or pupae without the full excavation of nests. All discovered larvae and pupae were counted and in addition from each Myrmica nest 10-20 worker ants were collected and preserved in alcohol. Identification keys by Czechowski et al. (2002) and Śliwinska et al. (2006) were used for species identification of Myrmica and Phengaris, respectively.

To quantify the strength of host specificity the $F$ index (proportion of adopted larvae that developed in nests of the primary host) of Thomas \& Elmes (1998) was calculated:

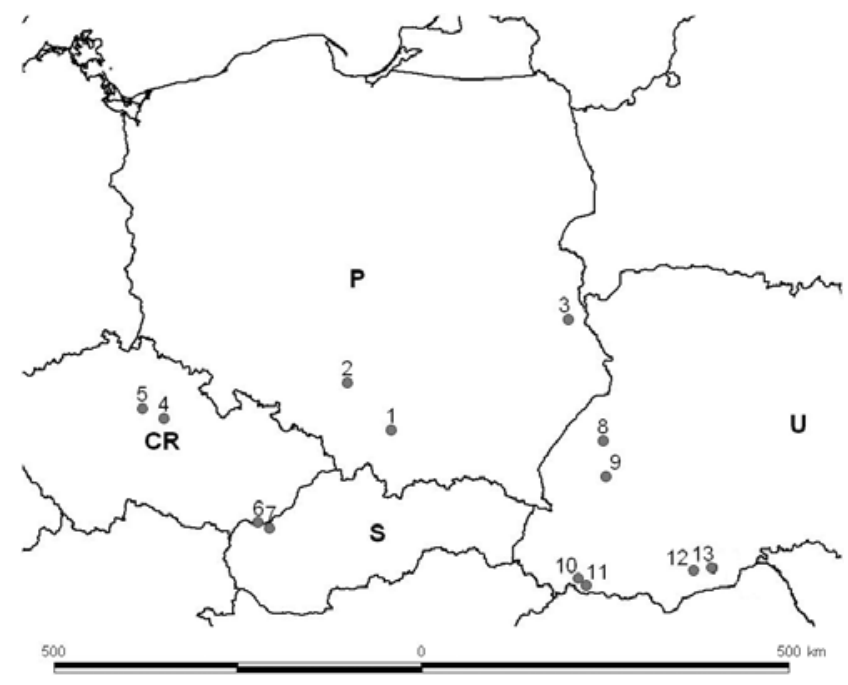

Fig. 1. Map with the sites at which Phengaris larvae or pupae were found (Poland: 1 - Kraków, 2 - Sliwa, 3 - Poleski National Park; Czech Republic: 4 - Přelouč, 5 - Poděbrady Kluk; Slovakia: 6 - Stefanova, 7 - Drgonova Dolina; Ukraine: 8 - Lviv Rudno, 9 - Rudniki, 10 - Kireshi, 11 - Novobarovo, 12 - Kosovanka, 13 - Stari Broskivci).

where: $a$ is the proportion of the Myrmica nests of the primary host species within $2 \mathrm{~m}$ from Phengaris host plants and $b$ is the proportion of fully grown Phengaris larvae or pupae found in those ant nests. Theoretically, $F$ can vary between 0 (no specificity) to $\infty$ (complete specificity).

\section{RESULTS}

P. teleius was the most abundant species found in 292 nests (at 10 localities) belonging to five Myrmica species (Table 1, Appendix 1). The percentage of nests infested by $P$. teleius ranged from $1.58 \%$ at Přelouč (the Czech Republic) to $10.75 \%$ in the Kraków region (Poland). Larvae and/or pupae of $P$. teleius were found mostly in M. scabrinodis and M. rubra nests. M. scabrinodis was present at all localities used as a host by P. teleius at seven of them, whereas M. rubra was present at six localities and used as a host at each of them (Table 1). Other species of Myrmica such as: M. ruginodis, M. gallienii Bondroit, 1919 and M. rugulosa Nylander, 1846 served as hosts locally, and in some cases a relatively high proportion of their nests was parasitized (Table 1). Interestingly, there were three cases of different host ants at close by localities (20-40 km from each other): Novobarovo and Kireshi (Ukraine), Rudniki and Lviv - Rudno (Ukraine) and Stefanova and Drgonova Dolina (Slovakia). Fisher exact tests or Chi square test were calculated separately for each site in order to compare frequencies of occupied and unoccupied nests for all the ant species at these sites. The only significant result was obtained for the Kraków region $\left(\chi^{2}=12.19\right.$, d.f. $\left.=3, \mathrm{P}=0.006\right)$. In this intensively sampled region $M$. scabrinodis was the most abundant Myrmica species but the percentage of parasitism was the lowest compared to the other ant species (Table 1). Additionally, $F$ indexes calculated for 6 populations of $P$. teleius showed that there was a mixed

$$
F=b(1-a) / a(1-b)
$$


TABle 1. Host ant use by P. teleius. The number of Myrmica nests at each site refers to areas of meadow within $2 \mathrm{~m}$ of $S$. officinalis.

\begin{tabular}{|c|c|c|c|c|c|}
\hline Site & Ant species & $\begin{array}{l}\text { Number of nests } \\
\text { in site }\end{array}$ & $\begin{array}{l}\text { Number and percentage } \\
\text { of nests with } P \text {. teleius }\end{array}$ & $\begin{array}{l}\text { Number of larvae/ } \\
\text { pupae of } P \text {. teleius }\end{array}$ & $\begin{array}{l}\text { Specificity } \\
(F)\end{array}$ \\
\hline \multirow{4}{*}{ Kraków (Poland) } & M. scabrinodis & $1585(68.4 \%)$ & $147(9.3 \%)$ & 220 & 0.55 \\
\hline & M. rubra & $392(16.9 \%)$ & $51(13.0 \%)$ & 87 & 1.3 \\
\hline & M. ruginodis & $299(12.9 \%)$ & $45(15.0 \%)$ & 94 & 1.99 \\
\hline & M. rugulosa & $40(1.8 \%)$ & $6(15.0 \%)$ & 8 & 1.18 \\
\hline \multirow{4}{*}{ Sliwa (Poland) } & M. scabrinodis & $98(73.8 \%)$ & $3(3.1 \%)$ & 3 & 0.53 \\
\hline & M. rubra & $16(12.0 \%)$ & $2(2.5 \%)$ & 4 & 4.9 \\
\hline & M. ruginodis & $1(0.7 \%)$ & - & & \\
\hline & M. gallienii & $18(13.5 \%)$ & - & & \\
\hline \multirow{2}{*}{ Novobarowo (Ukraine) } & M. scabrinodis & $200(99.5 \%)$ & $12(10.8 \%)$ & 20 & $\infty$ \\
\hline & M. ruginodis & $1(0.5 \%)$ & - & & \\
\hline \multirow{4}{*}{ Kireshi (Ukraine) } & M. scabrinodis & $6(5.8 \%)$ & - & & \\
\hline & M. rubra & $82(79.6 \%)$ & $3(3.7 \%)$ & 3 & $\infty$ \\
\hline & M. ruginodis & $1(1 \%)$ & - & & \\
\hline & M. gallienii & $14(13.6 \%)$ & - & & \\
\hline \multirow{3}{*}{ Rudniki (Ukraine) } & M. scabrinodis & $75(70.7 \%)$ & $7(9.3 \%)$ & 9 & 0.51 \\
\hline & M. rubra & $17(16.1 \%)$ & $2(11.8 \%)$ & 6 & 1.23 \\
\hline & M. gallienii & $14(13.6 \%)$ & $1(7.1 \%)$ & 1 & \\
\hline \multirow{4}{*}{ Lviv - Rudno (Ukraine) } & M. scabrinodis & $66(62.3 \%)$ & - & & \\
\hline & M. rubra & $9(8.5 \%)$ & $1(11.1 \%)$ & 1 & \\
\hline & M. ruginodis & $30(28.3 \%)$ & $2(6.7 \%)$ & 2 & \\
\hline & M. gallienii & $1(0.9 \%)$ & - & & \\
\hline \multirow{2}{*}{ Přelouč (Czech Rep.) } & M. scabrinodis & $188(98.9 \%)$ & $3(1.6 \%)$ & 3 & $\infty$ \\
\hline & M. ruginodis & $2(1.1 \%)$ & - & & \\
\hline \multirow{2}{*}{ Poděbrady - Kluk (Czech Rep.) } & M. scabrinodis & $41(61.2 \%)$ & $1(2.4 \%)$ & 1 & \\
\hline & M. sabuleti & $26(38.8 \%)$ & - & & \\
\hline \multirow[t]{2}{*}{ Stefanova (Slovakia) } & M. scabrinodis & $115(100 \%)$ & $4(3.5 \%)$ & 4 & \\
\hline & M. scabrinodis & $26(24.5 \%)$ & - & & \\
\hline \multirow[t]{2}{*}{ Drgonova Dolina (Slovakia) } & M. rubra & $78(73.6 \%)$ & $2(2.6 \%)$ & 2 & \\
\hline & M. ruginodis & $2(1.9 \%)$ & - & & \\
\hline
\end{tabular}

host used in the Kraków region (Poland), Sliwa (Poland) and Rudniki (Ukraine) (Table1).

P. nausithous was mostly associated with $M$. rubra $(23$ infested nests) and only in the Kraków region were its larvae occassionaly found in colonies of M. scabrinodis (2 nests) and $M$. ruginodis (2 nests). Larvae and pupae of $P$. alcon were found at four localities and invariably only M. scabrinodis (39 nests) was used as a host, even if other Myrmica species were abundant (Table 3). For the three populations of $P$. alcon investigated, $F$ values show that $M$. scabrinodis is the species' primary host.

Depending on the locality, the number of larvae/pupae per infested Myrmica nest ranged (mean and SE in parentheses) from: $1-8(2.2 \pm 0.281), 1-11(1.9 \pm 0.41), 1-11$ $(1.61 \pm 0.08)$ for $P$. alcon, $P$. nausithous and $P$. teleius, respectively and differed significantly between species (Kruskal-Wallis, $\chi^{2}=9.06$, d.f. $=2, \mathrm{P}=0.01$ ). Post hoc pairwise comparisons among groups (using Bonferonni correction, $\mathrm{P}=0.016$ ) revealed a significant difference between the number of larvae/pupae of $P$. alcon and $P$. teleius per infested Myrmica nest at all the localities (Mann-Whitney U Test, $\mathrm{P}=0.001$ ).

\section{DISCUSSION AND CONCLUSIONS}

Thomas et al. (2005) pointed out that the host specificity of social parasites of ants can increase as the results of better penetration of ant society and by interacting with ants in early stages of the life cycle. Thus, Phengaris should be species-specific in term of their host ants. However, the most recent data on host ant specificity in Phengaris butterflies contradicts this and in a few populations local specialization occurs (Als et al., 2002; Stankiewicz \& Sielezniew, 2002; Stankiewicz et al., 2005; Tartally \& Varga, 2005; Pech et al., 2007).

Data presented in this paper concern 10 populations of $P$. teleius from different geographical regions of Central Europe. Of the six potential host species present there $P$. teleius larvae used five of them, the exception being M. sabuleti. In Kraków, Sliwa and Rudniki, mixed host populations are used. Interestingly, the $F$ value (evaluates the strength of host specificity), is lower for M. scabrinodis than $M$. rubra and also lower than 1, which indicates lack of specificity for M. scabrinodis. These results are surprising, because the previous studies showed that the survival of $P$. teleius larvae reared in $M$. scabrinodis nests is five times greater than in the nests of other $M y r-$ mica species (Thomas et al., 1989; Thomas \& Wardlaw, 
TABLE 2. Host ant use by P. nausithous. The number of Myrmica nests at each site refers to areas of meadow within $2 \mathrm{~m}$ of $S$. officinalis.

\begin{tabular}{lccccc}
\hline Site & Ant species & $\begin{array}{c}\text { Number of nests } \\
\text { in site }\end{array}$ & $\begin{array}{c}\text { Number and percentage } \\
\text { of nests with P. nausithous }\end{array}$ & $\begin{array}{c}\text { Number of larvae/pupae } \\
\text { of P. nausithous }\end{array}$ & $\begin{array}{c}\text { Specificity } \\
(F)\end{array}$ \\
\hline Kraków & M. scabrinodis & $1585(68.4 \%)$ & $2(0.1 \%)$ & 3 & 0.03 \\
(Poland) & M. rubra & $392(16.9 \%)$ & $20(5.1 \%)$ & 28 & 23.8 \\
& M. ruginodis & $299(12.9 \%)$ & $2(0.7 \%)$ & & 4.4 \\
\hline Stari Broskivci & M. rugulosa & $40(1.8 \%)$ & - & 1 & \\
(Ukraine) & M. scabrinodis & $18(78.3 \%)$ & - & & \\
\hline \multirow{2}{*}{ Drgonova dolina } & M. rubra & $5(21.7 \%)$ & - & 3 & $\infty$ \\
(Slovakia) & M. rubrinodis & $26(24.5 \%)$ & $2(2.6 \%)$ & & \\
\hline & M. ruginodis & $2(1.9 \%)$ & - & & \\
\hline
\end{tabular}

1992). Results presented here show that in $70 \%$ of the localities investigated, where M. scabrinodis and $P$. teleius co-occurred, the former species was used as the host. However, it is important to note that M. scabrinodis is the most frequent Myrmica species found at P. teleius localities and this may account for why it is so frequently used as a host. Moreover, similar data from Asia, where several host ant species were recorded, including M. angulinodis Ruzsky, 1905 M. forcipata Karavaiev, 1931 M. kamtschatica Kupyanskaya, 1986 M. kurokii Forel, 1907 M. lobicornis Nylander, 1846, and M. ruginodis suggests multiple host use by $P$. teleius (for a review see Als et al., 2004, Woyciechowski et al., 2006). Furthermore, Aphaenogaster japonica Forel, 1911 was found to be parasitized by $P$. teleius in Japan (Yamaguchi, 1988), proving that Myrmica is not the only host genus. To sum up, the findings of earlier studies and those presented in this paper confirm the lack of specificity of $P$. teleius and shows that larvae of this butterfly can use almost every Myrmica species that co-occur in its habitat.

Larvae and pupae of $P$. nausithous were found in three different populations in Poland, Slovakia and Ukraine, in which $M$. rubra was predominantly used as the host. This confirms the findings of earlier studies (Thomas et al., 1989; Figurny \& Tomaszewicz, 1997; Stankiewicz \& Sie- lezniew, 2002; Tartally \& Varga, 2005) that $P$. nausithous almost exclusively uses $M$. rubra as its host across Europe. This high specificity is consistent with the finding that $M$. rubra has similar hydrocarbon profile over a wide geographical scale (from West Russia - near Moscow to West Scotland - Hebrides), which indicates that its colonies are chemically very similar across Europe (Elmes et al., 2002). Interestingly, in the Kraków region, we found two nests of $M$. scabrinodis and two M. ruginodis with larvae of $P$. nausithous. In this context, it is worth noting, that hydrocarbon profiles of $M$. ruginodis and $M$. rubra are chemically the most similar among the Myrmica species investigated by Elmes et al. (2002). The use of M. scabrinodis is also previously reported from Spain (Munguira \& Martín, 1997) and recently from Romania (Tartally et al., 2008). However, one cannot exclude the possibility that all these exceptions are cases in which $P$. nausithous larvae were initially adopted by a M. rubra colony, the nest site of which was subsequently abandoned and taken over by a colony of another species. It is known that switching nest sites is a typical behaviour of Myrmica ants (Elmes et al., 1998).

The $F$ values calculated for Polish populations of $P$. alcon revealed that $M$. scabrinodis is its primary host ant there. This is not surprising since at each locality all larvae were found exclusively in nests of this Myrmica

TABLE 3. Host ant use by P. alcon. The number of Myrmica nests at each site refers to areas of meadow where G. pneumonathe (the food plant of $P$. alcon) was present.

\begin{tabular}{|c|c|c|c|c|c|}
\hline Site & Ant species & $\begin{array}{l}\text { Number of nests } \\
\text { in site }\end{array}$ & $\begin{array}{l}\text { Number and percentage } \\
\text { of nests with } P \text {. alcon }\end{array}$ & $\begin{array}{l}\text { Number of larvae/ } \\
\text { pupae of } P \text {. alcon }\end{array}$ & $\begin{array}{l}\text { Specificity } \\
(F)\end{array}$ \\
\hline $\begin{array}{l}\text { Kraków } \\
\text { (Poland) }\end{array}$ & $\begin{array}{l}\text { M. scabrinodis } \\
\text { M. rubra } \\
\text { M. ruginodis } \\
\text { M. rugulosa }\end{array}$ & $\begin{array}{c}1116(68.6 \%) \\
275(16.9 \%) \\
225(13.9 \%) \\
10(0.6 \%)\end{array}$ & $\begin{array}{c}28(2.5 \%) \\
- \\
- \\
-\end{array}$ & 63 & $\infty$ \\
\hline $\begin{array}{l}\text { Sliwa } \\
\text { (Poland) }\end{array}$ & $\begin{array}{c}\text { M. scabrinodis } \\
\text { M. rubra } \\
\text { M. ruginodis } \\
\text { M. gallienii }\end{array}$ & $\begin{array}{c}98(73.8 \%) \\
16(12.0 \%) \\
1(0.7 \%) \\
18(13.5 \%) \\
\end{array}$ & $\begin{array}{c}2(2 \%) \\
- \\
- \\
- \\
\end{array}$ & 3 & $\infty$ \\
\hline $\begin{array}{l}\text { Poleski National } \\
\text { Park (Poland) }\end{array}$ & $\begin{array}{c}\text { M. scabrinodis } \\
\text { M. rubra } \\
\text { M. gallienii }\end{array}$ & $\begin{array}{c}59(83.1 \%) \\
8(11.3 \%) \\
4(5.6 \%) \\
\end{array}$ & $\begin{array}{c}2(3.4 \%) \\
- \\
-\end{array}$ & 8 & $\infty$ \\
\hline $\begin{array}{l}\text { Novobarovo } \\
\text { (Ukraine) }\end{array}$ & $\begin{array}{l}\text { M. scabrinodis } \\
\text { M. ruginodis }\end{array}$ & $\begin{array}{c}200(99.5 \%) \\
1(0.5 \%)\end{array}$ & $\begin{array}{c}7(3.5 \%) \\
-\end{array}$ & 13 & \\
\hline
\end{tabular}


species despite the presence of other potential host species such as $M$. rubra and $M$. ruginodis in the Kraków region and M. rubra and $M$. gallienii at Sliwa. Similar results for Poland are published by Sielezniew \& Stankiewicz (2001). Admittedly, the same authors also discovered two neighbouring populations of $P$. alcon in SE-Poland that simultaneously used M. scabrinodis and M. vandeli Bondroit, 1920 as host ants, but suspected that M. vandeli is a temporary social parasite of M. scabrinodis which is almost identical chemically (Radchenko et al., 2003; Sielezniew \& Stankiewicz, 2004; Stankiewicz et al., 2005). Pech et al. (2007) pointed out that firm evidence for local specialization of $P$. alcon exists only for a few Danish populations (Als et al., 2002; Nash et al., 2008) while other observations do not reveal any local specificity (Elmes et al., 2002; Schlick-Steiner et al., 2004). In contrast, our data clearly show that in all the Polish populations of $P$. alcon investigated high localspecialization occurs.

It is suggested that the cuckoo is more efficient than the predatory strategy (Elmes et al., 1991b) resulting in higher numbers of larvae/pupa produced per Myrmica nest. For a few populations of $P$. alcon, $P$. nausithous and $P$. teleius recorded by Thomas \& Elmes (1998) the mean number of larvae/pupae per infested nest was 6.0, 2.5 and 1.2 , respectively. In this study the corresponding figures are 2.2 for $P$. alcon, 1.9 for $P$. nausithous and 1.6 for $P$. teleius. Hence, even though the general pattern recorded in both studies is very similar, the main difference is in the number of $P$. alcon larvae/pupae per $M y r-$ mica nest. The sample size is almost the same in both studies (39 vs. 37 nests) but Thomas \& Elmes (1998) found quite a few nests with relatively high numbers $(>10)$ of $P$. alcon larvae. A possible reason could simply be a stochastic difference in the spatial overlap in the distribution of $G$. pneumonathe and ant nests which resulted in more Phengaris larvae entering Myrmica nests at the sites investigated by Thomas \& Elmes (1998). Another possible explanation is that Thomas \& Elmes (1998) sampled populations of $P$. alcon that used not only M. scabrinodis (as in the present study) but also M. rubra and $M$. ruginodis. It is known that $M$. rubra and $M$. ruginodis nests are usually larger than those of $M$. scabrinodis (Wardlaw \& Elmes 1996; Radchenko et al., 1997; Skórka et al., 2006) and thus likely support more Phengaris larvae.

To summarise, this study confirms the high specificity of $P$. nausithous for $M$. rubra throughout its distribution range and recorded a new host (M. ruginodis) for this species. The results also indicate that $P$. teleius does not show either species-specificity or local specialization to host ants. Additionally, our findings clearly show a high local specialisation of $P$. alcon populations with $M$. scabrinodis being the primary host. This Myrmica species is the most common host ant of $P$. alcon in East-central Europe, although other species such as M. vandeli or $M$. salina are used occasionally (Sielezniew \& Stankiewicz, 2001; Tartally, 2005; Tartally et al., 2008).
Similar to Pech et al. (2007) we think that the regional host species pool is one of the most important factors affecting the host ant specificity of Phengaris butterflies, and that stating that a butterfly is specialised to a specific ant at a particular site, if is not supported by data "may lead to erroneous management prescriptions" (Pech at al., 2007, page 15). But, we also argue that insufficient information on host specificity may have the same effect (as was shown for $P$. arion by Thomas 1980, 1995, Thomas et al., 1998). Therefore it is important to further investigate this aspect of the Large Blues' biology in order to improve management concepts (compare Johst et al., 2006; Drechsler et al., 2007), while in parallel we might be forced to mimic land-use systems as surrogate for the ants' requirements as long as these are not sufficiently known.

ACKNOWLEDGEMENTS. We would like to thank A. Amirowicz, J. Woyciechowski, K. Woyciechowski, H. Veselá, H. Lálová, J. Bouberlová, J. Cibulka and H. Ver for their help with the fieldwork. We are also grateful to staff of the Tchernovtsy University in the Ukraine and P. Devan from The Protected Landscape Park Biele Karpaty for logistic support during our trip to the Ukraine and Slovakia, respectively. Z. Randle improved the English of the manuscript. The study was financed by the EC within its Framework 5RTD project Macman (EVK2CT-2001-00126), by the Polish Ministry of Science and Higher Education (grant SPUB-3024) and by Czech University of Life Sciences (grant MSM6046070901). P. Skórka and M. Witek were beneficiaries of the Foundation for Polish Science. We thank two anonymous referees for a very productive discussion, which helped to improve the manuscript.

\section{REFERENCES}

Als T.D., Nash D.R. \& Boomsma J.J. 2002: Geographical variation in host ant specificity of the parasitic butterfly Maculinea alcon in Denmark. Ecol. Entomol. 27: 403-414.

Als T.D., Vila R., Kandul N.P., Nash D.R., Yen S.-H., Hsu Y.-F., Mignault A.A., Boomsma J.J. \& Pierce N.E. 2004: The evolution of alternative parasitic life histories in large blue butterflies. Nature 432: 386-390.

Cottrell C.B. 1984: A phytophagy in butterflies: its relationship to myrmecophily. Zool. J. Linn. Soc. 79: 1-57.

Czechowski W., Radczenko A. \& Czechowska W. 2002: The Ants (Hymenoptera, Formicidae) of Poland. Museum \& Institute of Zoology, Warszawa, $200 \mathrm{pp}$.

Drechsler M., Watzold F., Johst K., Bergmann H. \& Settele J. 2007: A model-based approach for designing cost-effective compensation payments for conservation of endangered species in real landscapes. Biol. Conserv. 140: 174-186.

Elmes G.W., Thomas J.A. \& Wardlaw J.C. 1991a: Larvae of Maculinea rebeli, a large blue butterfly, and their Myrmica host ants: wild adoption and behaviour in ant-nests. J. Zool. 223: 447-460.

Elmes G.W., Wardlaw J.C. \& Thomas J.A. 1991b: Larvae of Maculinea rebeli, a large blue butterfly, and their Myrmica host ants: patterns of caterpillar growth and survival. J. Zool. 224: 79-92.

Elmes G.W., Thomas J.A., Hammarstedt O., Munguira M.L., Martín J. \& VAN Der MAdE J.G. 1994: Differences in host-ant specificity between Spanish, Dutch and Swedish populations of the endangered butterfly Maculinea alcon (Denis et Schiff.) (Lepidoptera). Mem. Zool. 48: 55-68. 
Elmes G.W., Thomas J.A., Wardlaw J.C., Hochberg M.E., Clarke R.T. \& Simcox D.J. 1998: The ecology of Myrmica ants in relation to the conservation of Maculinea butterflies. J. Insect Conserv. 2: 67-78.

Elmes G.W., Akino T., Thomas J.A., Clarke R.T. \& Knapp J.J. 2002: Interspecific differences in cuticular hydrocarbon profiles of Myrmica ants are sufficiently consistent to explain host specificity by Maculinea (large blue) butterflies. Oecologia 130: 525-535.

FIEDLER K. 1991: Systematics, evolutionary, and ecological implications of myrmecophily within the Lycaenidae (Insecta: Lepidoptera: Lycaenidae). Bonn. Zool. Monogr. No 3: $1-210$.

FIEDLER K. 2001: Ants that associate with Lycaeninae butterfly larvae: diversity, ecology and biogeography. Divers. Distrib. 7: 45-60.

Figurny E. \& Tomaszewicz S. 1997: [Parasitism of Maculinea teleius (Lepidoptera: Lycaenidae) and M. nausithous in Myrmica scabrinodis and M. rubra ant nests.] In: Wspótczesne kierunki Ekologii, Ekologia Behawioralna. Lublin, pp. 179-184.

Fric Z., Wahlberg N., Pech P. \& Zrzavý J. 2007: Phylogeny and classification of the Phengaris - Maculinea clade (Lepidoptera: Lycaenidae): total evidence and phylogenetic species concepts. Syst. Entomol. 32: 558-567.

Johst K., Drechsler M., Thomas J. \& Settele J. 2006: Influence of mowing on the persistence of two endangered large blue butterfly species. J. Appl. Ecol. 43: 333-342.

KudRnA O. 2001: Miscellaneous notes on the taxonomy of four European butterflies (Lepidoptera: Rhopalocera). Entomol. Gaz. 52: 253-261.

Maschwitz U., Schroth M., Hänel H. \& Tho Y.P. 1984: Lycaenids parasitizing symbiotic plant-ant partnership. Oecologia 64: 78-80.

Munguira M.L. \& Martín J. 1997: Action Plan for the Maculinea Butterflies in Europe. Nature and Environment, No. 97. Council of Europe Publishing, Strasboug, 64 pp.

Nash D.R., Als T.D., Maile R., Jones G.R. \& Boomsma J.J. 2008: A mosaic of chemical coevolution in a large blue butterfly. Science 319: 88-90.

Pech P., Fric Z. \& KonvičKa M. 2007: Species-specificity of the Phengaris (Maculinea) - Myrmica host system: Fact or myth? (Lepidoptera: Lycaenidae; Hymenoptera: Formicidae). Sociobiology 50: 983-1003.

PIERCE N.E. 1987: The evolution and biogeography of associations between lycaenid butterflies and ants. Oxford Surv. Evol. Biol. 4: 89-116.

Radchenko A., Czechowski W. \& Czechowska W. 1997: The genus Myrmica Latr. (Hymenoptera, Formicidae) in Poland a survey of species and key for their identification. Ann. Zool. 47: 481-500

Radchenko A., Elmes G.W., CzechowsKa W., Stankiewicz A., Czechowski W. \& Sielezniew M. 2003: First records of Myrmica vandeli Bondroit and M. tulinae Elmes, Radchenko et Aktac (Hymenoptera: Formicidae) for Poland, with a key for the scabrinodis and sabuleti-complex. Fragm. Faun. 46: 47-57.

Schlick-Steiner B.C., Steiner F.M., Höttinger H., Nikiforov A., Mistrik R., Schafellner C., Baier P. \& Christian E. 2004: A butterfly's chemical key to various ant forst: intersection-odour or aggregate-odour multi-host mimicry? Naturwissenschaften 91: 209-214.

Sielezniew M. \& Stankiewicz A. 2001: First data on host-ant specificity of parasitic Maculinea alcon (Den. \& Schiff.) (Lepidoptera: Lycaenidae) in Poland and eastern Europe. Fragm. Faun. 45: 123-130.
Sielezniew M. \& Stankiewicz A. 2004: Simultaneous exploitation of Myrmica vandeli and M. scabrinodis (Hymenoptera: Formicidae) colonies by the endangered myrmecophilous butterfly Maculinea alcon (Lepidoptera: Lycaenidae). Eur. J. Entomol. 101: 693-696.

Skórka P., Witek M. \& Woyciechowski M. 2006: A simple and nondestructive methods for estimation of worker population size in Myrmica ant nests. Insectes Soc. 53: 97-100.

Śliwinska E.B., Nowicki P., Nash D.R., Witek M., Settele J. \& WoYcIECHOWSKI M. 2006: Morphology of caterpillars and pupae of European Maculinea species (Lepidoptera: Lycaenidae) with identification table. Entomol. Fenn. 17: 351-358.

Stankiewicz A. \& Sielezniew M. 2002: Host specificity of Maculinea teleius Bgstr. and M. nausithous Bgstr. (Lepidoptera: Lycaenidae). The new insight. Ann. Zool. 52: 403-408.

Stankiewicz A., Sielezniew M. \& Buszko J. 2005: Maculinea alcon and M. rebeli in Poland: distribution, habitats, host ant specificity and parasitoids. In Settele J., Kühn E. \& Thomas J.A. (eds): Studies on the Ecology and Conservation of Butterflies in Europe. Vol. 2. Species Ecology along a European Gradient: Maculinea Butterflies as a Model. Pensoft Publishers, Sofia, Moscow, pp. 90-93.

Tartally A. 2005: Myrmica salina (Hymenoptera: Formicidae) as a host of Maculinea alcon (Lepidoptera: Lycaenidae). Sociobiology 46: 39-43.

TARTAlly A. \& Csösz S. 2004: [Data on the ant hosts of the Maculinea butterflies (Lepidoptera: Lycaenidae) of Hungary.] Természet. Közlem. 11: 309-317 [in Hungarian].

Tartally A. \& Varga Z. 2005: Myrmica rubra (Hymenoptera: Formicidae): the first data on host-ant specificity of Maculinea nausithous (Lepidoptera: Lycaenidae) in Hungary. Myrmecol. Nachr. 7: 55-59.

Tartally A., Rákosy L., Vizauer T.C., Goia M. \& Varga Z. 2008: Maculinea nausithous exploits Myrmica scabrinodis in Transylvania: unusual host ant species of a myrmecophilous butterfly in an isolated region (Lepidoptera: Lycaenidae, Hymenoptera: Formicidae). Sociobiology 51: 373-380.

Tartally A., Nash D.R, Lengyel S. \& Varga Z.: Patterns of host ant use by sympatric populations of Maculinea alcon and M. "rebeli" in the Carpathian Basin. Insectes Soc. In press.

Thomas J.A. 1980: Why did the Large Blue become extinct in Britan? Oryx 15: 243-247.

THOMAs J.A. 1995: The ecology and conservation of Maculinea arion and other European species of large blue butterfly. In Pullin A.S. (ed.): Ecology and Conservation of Butterflies. Chapman and Hall, London, pp. 180-197.

Thomas J.A. \& Elmes G.W. 1998: Higher productivity at the cost of increased host-specificity when Maculinea butterfly larvae exploit ant colonies through trophallaxis rather than by predation. Ecol. Entomol. 23: 457-464.

Thomas J.A. \& Settele J. 2004: Butterfly mimics of ants. Nature 432: 283-284.

ThOMAS J.A \& WARdLAW J.C. 1992: The capacity of a Myrmica ant nest to support a predacious species of Maculinea rebeli inhabitants in ant nests. Oecologia 91: 101-109.

Thomas J.A., Elmes G.W., Wardlaw J.C. \& Woyciechowski M. 1989: Host specificity among Maculinea butterflies in Myrmica ant nests. Oecologia 79: 452-457.

Thomas J.A., Manguira M.L., Martin J. \& Elmes G.W. 1991: Basal hatching in Maculinea butterfly eggs: a consequence of advanced myrmecophily? Biol. J. Linn. Soc. 4: 175-184.

Thomas J.A., Elmes G.W. \& Wardlaw J.C. 1993: Contest competition among Maculinea rebeli butterfly larvae in ant nests. Ecol. Entomol. 18: 73-76.

Thomas J.A., Simcox D.J., Wardlaw J.C., Elmes G.W., Hochberg M.E. \& Clarke R.T. 1998: Effects of latitude, alti- 
tude and climate on the habitat and conservation of the endangered butterfly Maculinea arion and its Myrmica ant hosts. $J$. Insect Conserv. 2: 39-46.

Thomas J.A., Schönrogge K. \& Elmes G.W. 2005: Specializations and host associations of social parasites of ants. In Fellowes M.D.E., Holloway G.J. \& Rolff J. (eds): Insect Evolutionary Ecology. CABI, Wallingford, pp. 475-514.

Wardlaw J.C. \& Elmes G.W. 1996: Exceptional colony size in Myrmica species (Hymenoptera: Formicidae). Entomologist 115: 191-196.
Witek M., Sliwinska E., Skorka P., Nowicki P., Settele J. \& WoyciechowsKi M. 2006: Polymorphic growth in larvae of Maculinea butterflies, as an example of biennialism in myrmecophilous insects. Oecologia 148: 729-733.

Woyciechowski M., SLOWIK J. \& MueHlenberg M. 2006: Hosts of the butterfly Maculinea teleius among Myrmica ants in northern Mongolia. Sociobiology 48: 493-502.

Yamaguchi S. 1988: The Life Histories of Five Myrmecophilous Lycaenid Butterflies of Japan. Kondansha, Tokyo.

Received April 22, 2008; revised and accepted July 30, 2008

APPENDIX 1. Phengaris butterfly and Myrmica ant species composition of the sites investigated (* imagoes observed, but no larvae or pupae found).

\begin{tabular}{|c|c|c|c|c|}
\hline Site name and its number on Fig. 1 & Geographical position & Phengaris species & Myrmica species & Number of nests found \\
\hline \multicolumn{5}{|l|}{ Poland } \\
\hline Kraków (1) & $50^{\circ} 01^{\prime} \mathrm{N} ; 1^{\circ} 53^{\prime} \mathrm{E}$ & $\begin{array}{c}\text { P. teleius } \\
\text { P. nausithous } \\
\text { P. alcon }\end{array}$ & $\begin{array}{l}\text { M. scabrinodis } \\
\text { M. rubra } \\
\text { M. ruginodis } \\
\text { M. rugulosa }\end{array}$ & $\begin{array}{c}1585 \\
392 \\
299 \\
40\end{array}$ \\
\hline Sliwa (2) & $50^{\circ} 35^{\prime} \mathrm{N} ; 19^{\circ} 02^{\prime} \mathrm{E}$ & $\begin{array}{l}\text { P. teleius } \\
\text { P. alcon }\end{array}$ & $\begin{array}{l}\text { M. scabrinodis } \\
\text { M. rubra } \\
\text { M. ruginodis } \\
\text { M. gallienii }\end{array}$ & $\begin{array}{c}98 \\
16 \\
1 \\
18\end{array}$ \\
\hline Poleski National Park (3) & $51^{\circ} 21^{\prime} \mathrm{N} ; 23^{\circ} 19^{\prime} \mathrm{E}$ & $\begin{array}{c}\text { P. alcon } \\
\text { P. teleius* } \\
\text { P. arion* }\end{array}$ & $\begin{array}{c}\text { M. scabrinodis } \\
\text { M. rubra } \\
\text { M. gallienii }\end{array}$ & $\begin{array}{c}59 \\
8 \\
4 \\
\end{array}$ \\
\hline \multicolumn{5}{|l|}{ Czech Republic } \\
\hline Přelouč (4) & $50^{\circ} 02^{\prime} \mathrm{N} ; 15^{\circ} 34^{\prime} \mathrm{E}$ & $\begin{array}{c}\text { P. teleius } \\
\text { P. nausithous* }\end{array}$ & $\begin{array}{l}\text { M. scabrinodis } \\
\text { M. ruginodis }\end{array}$ & $\begin{array}{c}188 \\
2\end{array}$ \\
\hline Poděbrady - Kluk (5) & $50^{\circ} 07^{\prime} \mathrm{N} ; 15^{\circ} 08^{\prime} \mathrm{E}$ & P. teleius & $\begin{array}{l}\text { M. scabrinodis } \\
\text { M. sabuleti }\end{array}$ & $\begin{array}{l}41 \\
26\end{array}$ \\
\hline \multicolumn{5}{|l|}{ SLOVAKIA } \\
\hline Stefanova (6) & $48^{\circ} 50^{\prime} \mathrm{N} ; 17^{\circ} 27^{\prime} \mathrm{E}$ & P. teleius & M. scabrinodis & 115 \\
\hline Drgonova dolina (7) & $48^{\circ} 46^{\prime} \mathrm{N} ; 17^{\circ} 40^{\prime} \mathrm{E}$ & $\begin{array}{c}\text { P. teleius } \\
\text { P. nausithous }\end{array}$ & $\begin{array}{l}\text { M. scabrinodis } \\
\text { M. rubra } \\
\text { M. ruginodis }\end{array}$ & $\begin{array}{c}26 \\
78 \\
2 \\
\end{array}$ \\
\hline \multicolumn{5}{|l|}{ UKRAINE } \\
\hline Novobarovo (11) & $48^{\circ} 05^{\prime} \mathrm{N} ; 23^{\circ} 30^{\prime} \mathrm{E}$ & $\begin{array}{l}\text { P. teleius } \\
\text { P. alcon }\end{array}$ & $\begin{array}{l}\text { M. scabrinodis } \\
\text { M. ruginodis }\end{array}$ & $\begin{array}{c}200 \\
1 \\
\end{array}$ \\
\hline Kireshi (10) & $48^{\circ} 11^{\prime} \mathrm{N} ; 23^{\circ} 21^{\prime} \mathrm{E}$ & P. teleius & $\begin{array}{l}\text { M. scabrinodis } \\
\text { M. rubra } \\
\text { M. ruginodis } \\
\text { M. gallienii }\end{array}$ & $\begin{array}{c}6 \\
82 \\
1 \\
14\end{array}$ \\
\hline Rudniki (9) & $49^{\circ} 25^{\prime} \mathrm{N} ; 23^{\circ} 56^{\prime} \mathrm{E}$ & P. teleius & $\begin{array}{c}\text { M. scabrinodis } \\
\text { M. rubra } \\
\text { M. gallienii }\end{array}$ & $\begin{array}{l}75 \\
17 \\
14 \\
\end{array}$ \\
\hline Lviv - Rudno (8) & $49^{\circ} 51^{\prime} \mathrm{N} ; 23^{\circ} 54^{\prime} \mathrm{E}$ & P. teleius & $\begin{array}{l}\text { M. scabrinodis } \\
\text { M. rubra } \\
\text { M. ruginodis } \\
\text { M. gallienii }\end{array}$ & $\begin{array}{c}66 \\
9 \\
30 \\
1\end{array}$ \\
\hline Stari Broskivci (13) & $48^{\circ} 14^{\prime} \mathrm{N} ; 25^{\circ} 48^{\prime} \mathrm{E}$ & $\begin{array}{l}\text { P. nausithous } \\
\text { P. teleius }\end{array}$ & $\begin{array}{c}\text { M. scabrinodis } \\
\text { M. rubra }\end{array}$ & $\begin{array}{c}18 \\
5 \\
\end{array}$ \\
\hline Kosovanka (12) & $48^{\circ} 13^{\prime} \mathrm{N} ; 25^{\circ} 28^{\prime} \mathrm{E}$ & $\begin{array}{l}\text { P. teleius* } \\
\text { P. nausithous* } \\
\text { P. arion* }\end{array}$ & $\begin{array}{c}\text { M. scabrinodis } \\
\text { M. rubra }\end{array}$ & $\begin{array}{c}24 \\
1\end{array}$ \\
\hline
\end{tabular}

